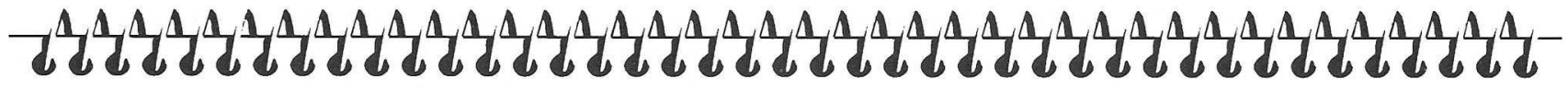

\section{腸内フローラの構成と機能をめぐる 新たな展開}

\section{伊藤喜久治}

東京大学大学院農学生命科学研究科

腸内フローラは光の構成, 機能面から多くの研究が進めら れ，予防医学や健康指向の高まりから，弚の重要性に対する 認識がますます強まってきた。腸内フローラは宿主にとって 有害にも有益にも働くが，乥のメカニズムについては不明な 点が多くほとんど解明されていない。しかし最近, バイオサ イエンス分野で新たな知見や新しい実験手技が開発され，新 たな展開をみせている。

ヒトや動物の腸内に生息する細菌の集団，腸内フロー ラ(図 1)の機能が注目されるようになったのは，コーグ ルトが腸内腐敗を抑制することで長寿効果をもつという メチニコフの不老長寿説，パスッールによる「腸内細菌 は動物生存にとっては必要不可欠なものである」という 腸内細菌有用論に始まる。それを科学的に明らかにする ために, パスッールの説から約 60 年後にレイヤニスら によって成功したラットの無菌繁殖，ならびに腸内フロ 一ラ構成菌を明らかにする種々の研究から開発された腸 内嫌気性菌を培養する技術が大きな役割を果たしてき た。ここまでを腸内フローラ研究の第一段階とすると， 第二段階では，これらの技術を用いた腸内フローラと宿 主との関係の実証ならびに疫学調査により, 腸内フロー
ラの役割が次々と明らかになってきた。

そして第三段階として，マイクロアレイを用いた宿主 の遺伝子レベルでの解析，16S rDNA の塩基配列を用い た細菌の分類, PCR 法, in situ hybridization (FISH) 法を用いた腸内菌の検出法，人工腸管を用いた ex-vivo システムの開発, 実験動物としての遺伝子改変動物の作

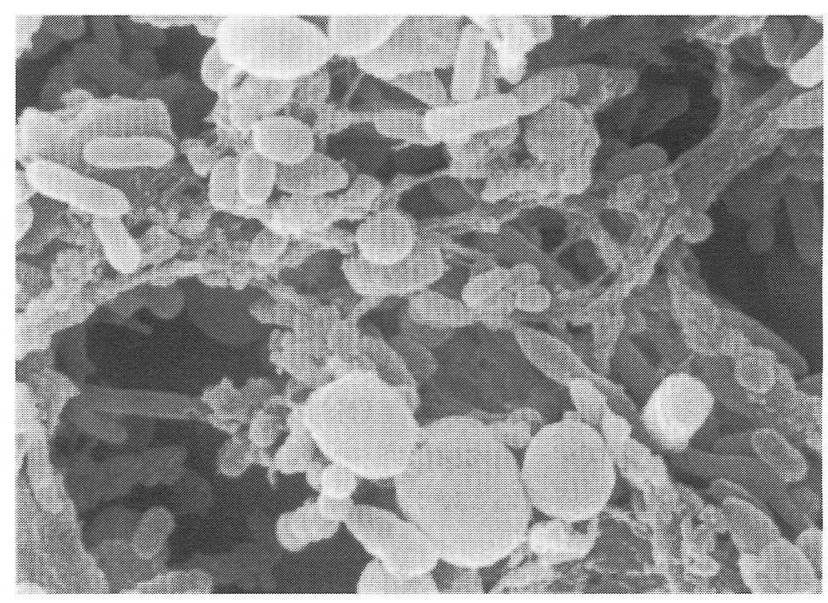

図 1 ロヒト黉便中の腸内フローラ (走査電子顕微鏡写真) 
出など，新技術を用いた宿主と腸内フローラの “crosstalk”の解析へと進んできた. 本稿では，これまでに明ら かにされた腸内フローラの機能と構成ならびに今後の研 究の方向について紹介する.

\section{宿主と腸内フローラとの関係}

腸内フローラが宿主の生体恒常性や病態に深く関わっ ていることは疑う余地がない.これについては，無菌動 物と通常動物の比較研究において既知の細菌を無菌動物 に定着させたノトバイオートでの成績が宿主と腸内フロ ーラの関係を実証し，ヒトや通常動物での腸内フローラ 構成の解析, 䔬便中に含まれる腸内容物の各種物質の解 析などにより明らかにされてきた ${ }^{(1)}$.

近年は, 腸内フローラの研究はプロバイオティクス (Probiotics), プレバイオティクス (Prebiotics), バイ オジェニックス (Biogenics)，といった観点から，機能 性食品の生体生理や病態との関係を腸内フローラを介し て行なう研究がその主なものとなってきた ${ }^{(2)} .1991$ 年 にスタートした「特定保健用食品」の制度もこれらの研 究開発の後押しをした。

\section{1. 発癌抑制効果}

腸内フローラの発癌, 特に大腸癌への影響について は, 食餪成分との関係で研究が進められた。いわゆる “西洋食”, つまり高脂肪, 高タンパク質, 低繊維の食餌 は大腸癌を誘発することが, 疫学調査や動物実験で明ら かにされた。発癌における腸内フローラの役割について 図 2 に示す.

1979 年に, 腸内フローラ構成の違いが発癌に影響す ることが $\mathrm{C} 3 \mathrm{H} / \mathrm{He}$ マウスの肝癌の自然発癌を利用した
各種ノトバイオートで示された ${ }^{(3)}$. 発癌率が, 無菌マ ウスでは 30\%, 通常マウスでは $75 \%$, Bifidobacterium longum 単独投与マウスでは $47 \%$, 大腸菌, 腸球菌, Clostridium paraputrificum 2 株を投与したマウス群 では $100 \%$ となり，これにB. longum を加えた 5 株の投 与では $46 \%$ となった. しかし, そのメカニズムについて は依然明らかにされていない。

プロバイオティクスやプレバイオティクスの投与が発 癌を抑制するという報告は多く, メカニズムとして以下 の 7 つが考えられる. (1) natural killer (NK) 細胞の活 性化, (2)腸内細菌による発癌物質や発癌プロモーター,

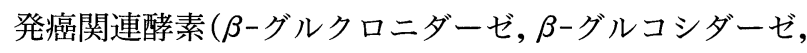
ニトロリラクターゼなど）の産生抑制, (3)へテロサイク リックアミンを活性化する腸内菌の抑制, (4)発癌物質の 吸着, (5)短鎖脂肪酸, 特に酪酸のような抗腫瘍, 抗変異 原物質の産生, (6)胆汁酸代謝による二次胆汁酸の産生抑 制, (7) $\mathrm{pH}$ などの腸内生理状態の変化, である.また, 疫学調查や臨床試験においてはプロバイオティクス，プ レバイオティクスの摂取によるヒトの大腸癌の予防を示 す報告はみられない. しかし, 膀胱癌についての疫学調 查によると, Lactobacillus casei を長期間捸取したグル ープは搨取しないグループに比べて発症率が低いとされ ている. また大腸癌切除後の再発率については, 乳酸菌 摂取群は対照群に比べて低く, 食物繊維摂取群ではこの 効果はみられない.

腸内菌が直接関与する二次胆汁酸の生成に関しては, 肝臓から分泌される抱合型胆汁酸を脱抱合する菌群，な らびに一次胆汁酸を二次胆汁酸に変換する菌群におい て, in vitroですでに多くの報告がある. 脱抱合には, ヒ卜腸内に優勢に生息するBacteroides, Eubacterium など多くの菌種が関与するが，デオキシコール酸の生成

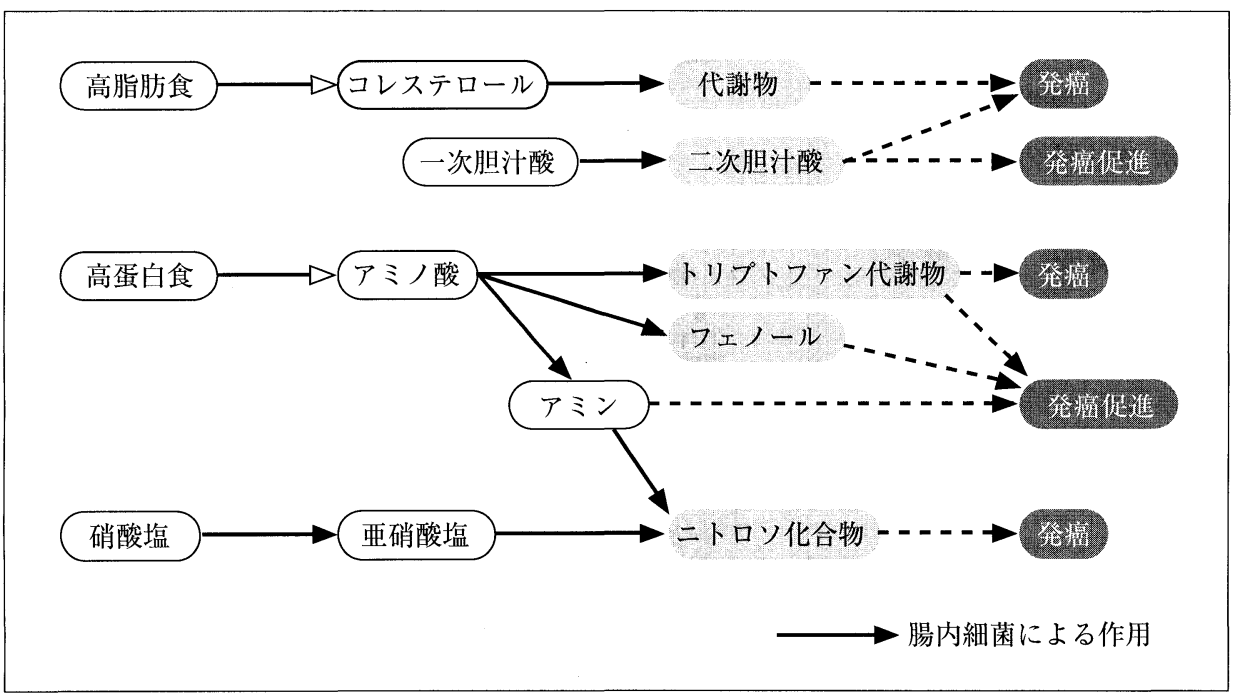

図 2 - 発癌における腸内細菌の 役割（光岡原図を改変） 
ラテン語の “gnotobiote“の “gnoto” は「知る」という意味で, ノトバイ オートは「存在する全ての生物が明らかな生物」と定義 される. 無菌生物に 1 種から多種の既知の細菌を定着さ せたもので，定着した菌の種類が明らかに識別できるも のをいう，無菌動物も 1 つのノトバイオートで，その動 物以外の生物の存在しない動物を意味する。

Probiotics：1989 年 Fullerにより，「腸内微生物のバ ランスを改善することにより宿主に有益 に働く生菌添加物」と定義されている. 各種生菌剤や乳 酸菌飲料がこれに含まれる。

Prebiotics : 1995 年 Gibson and Robenfroid により, 「結腸内に生息する有用菌の増殖ならびに その活性を促進することにより宿主の健康に有益に作用 する難消化性食品成分」と定義されている，多種オリゴ糖 はその代表である.

Biogenics： 1998 年光岡により，「腸内フローラを介 テロール低下作用など生体調節・生体防御・老化制御な どに働く食品成分」と定義され乳酸菌発酵産物, カテキ ン， $\beta$-カロチンなどが含まれる。

に関与する $7 \alpha$-デヒドロキシラーゼ活性を示す菌種は Clostridium，Eubacterium の中でも限られた菌種で， 腸内では $10^{8} / \mathrm{g}$ 以下とみられる。これらの活性をもつ菌 株をin vivoつまり無菌動物に経口投与しても，腸内に その活性はみられないか非常に低く, in vitro と in vivo の活性が一致しない(4).これは，腸内環境がこれらの酵 素の生成を調整しているためと考えられる。

以上，発癌と腸内フローラとの関係，またプロバイオ ティクス，プレバイオティクスの発癌抑制効果について 述べてきたが，プロバイオティクス，プレバイオティク スの定義にもあるような「腸内微生物のバランスを改善 することにより」という点は，依然不明なまま残されて いる. rasH2 マウス（ヒトのプロトタイプ c-Ha-ras 遺 伝子を導入したトランスジェニックマウス）を用いた筆 者らの実験では，1,2-ジメチルヒドラジン誘発の大腸癌 の発生を, Bifidobacterium longum や 4 種の乳酸菌の 発酵産物やヨーグルト，アップルペクチンなどが有意に

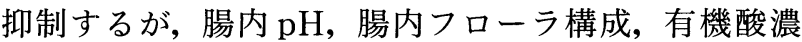
度, 胆汁酸濃度, 腸内腐敗産物濃度などの腸内環境は対 照群と差がなく，腸内環境と発癌についてはさらに検討 しなければならない( ${ }^{(5)}$.

\section{2.アレルギー抑制効果}

腸内フローラは粘膜免疫機構の発達になくてはならな いものであり，無菌マウスでは IgA の産生が著しく低 く，免疫寛容が成立しない。最近，小児アレルギーと腸
ヘテロサイクリックアミン： タンパク質の豊富な食品 を加熱料理中に生成され る発癌物質. Trp-P-2, PhIP, IQ などが含まれる.

SPF : Specific pathogen free の略. 動物固有の病原 体がいない動物を SPF 動物という。実験動物で は，帝王切開や子宮切除により無菌動物としたものをバ リヤー施設に搬入し，繁殖させて作出する。

SAMp1/Y4：老化促進マウス (Senescence-accelerated mouse；SAM）の一系統である SAMP1 から老化徴候やアミロイドーシスを示さず，皮 膚炎と小腸炎を発症する系統を選抜飼育して樹立したマ ウス系統。小腸炎をほほ $100 \%$ 発症する。

腸内腐敗：腸内細菌により腸内に腐敗産物といわれる アンモニア，インドール，フェノールなどが 異常に産生される状態をいう.

Stx : シガトキシン赤痢菌の産生するトキシンとして同 定された。その後, 腸管出血性大腸菌 (EHEC；

Escherichia coli O157，H7 など）の産生する Verotoxin $(\mathrm{VT})$ も同様のトキシンと同定され, EHEC の産生するト キシンはVTから Stx と変更された。

内フローラとの関係がクローズアップされている，小児 アレルギー患者では健康な小児に比べて, 腸内の Bifidobacterium やLactobacillus の菌数が少なく, Bifidobacterium の菌種も異なる。こうした小児アレルギー患 者に Lactobacillus や Bifidobacterium を投与するとア レルギー症状が軽減されることが示されている ${ }^{(6)}$.この 効果は生後 4 歳までの追跡調査でも持続した.

腸管免疫では抗原の種類により誘導される $\mathrm{T}$ 細胞 が異なる．T 細胞には，その産生するサイトカインであ る $\gamma$-インターフェロン $(\gamma$-IFN $)$ ，インターロイキンー 2(IL-2)が主となる Th1 型と，IL-4，5，10，13 などが
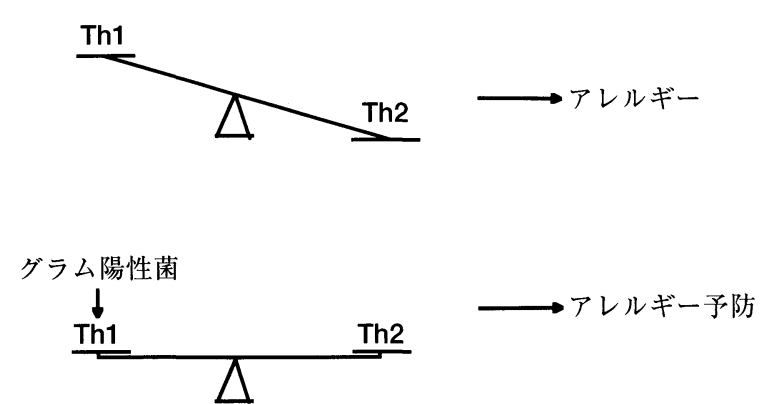

$\begin{array}{ll}\text { 細胞性免疫 } & \text { 液性免疫 } \\ \text { IL-2 } & \text { IL-4 } \\ \text { IFN- } \beta & \text { IL-5 } \\ \text { TNF- } \beta & \text { IL-13 }\end{array}$

図 3 - 腸管粘膜の Th1/Th2 バランスとアレルギー 
主となる $\mathrm{Th} 2$ 型があり, 前者は細胞性免疫を, 後者は 液性免疫を誘導する。このバランスが Th2 型に傾くと アレルギーが発症する(図 3)。一般にグラム陽性菌は Th1 型, グラム陰性菌は Th2 型を誘導する. グラム陽 性菌である Lactobacillus や Bifidobacterium の投与に よって Th1 が誘導されアレルギー症状の軽減につなが ったものと考えられる. 一方, プロバイオティクスとし て大腸菌を投与した場合も, 20 歳までの追跡調查でア レルギーの低減効果がみられたとの報告もあり ${ }^{(7)}$, 腸内 フローラやプロバイオティクスによるアレルギー低減作 用は Th1 と Th2 のバランス調整によることが強く示唆 される.また，プレバイオティクスの投与でもアレルギ 一の抑制効果が報告されているが，動物実験では必ずし も腸内の Lactobacillus や Bifidobacterium の増加を伴 わない. 当然, ヒトとマウスでは腸内フローラ構成が大 きく異なるが, 腸内フローラを介しての効果について, 有機酸の作用も含め検討が必要である.

\section{3. 炎症性腸疾患への治療効果}

炎症性腸疾患（inflamatory bowel disease；IBD）で あるクローン病 (Crohn's disease；CD), 潰瘍性大腸炎 (ulcerative colitis；UC) などは粘膜免疫機構の破綻や 未熟性が主要な病因と考えられている. IBD の動物モ デルとして，デキストラン硫酸やハプテンであるトリニ トロベンゼンスルホン酸（TNBS）などの薬物投与, 遺 伝子改変動物, 自然発症の病態モデル動物, 細胞導入な どが報告されている.このうち免疫機構の遺伝子改変動 物，たとえば IL-2, IL-10, T 細胞受容体 $\alpha$ 遺伝子の八 ックアウトマウスやヒト HLA-B27/p2 シクログロブリ ン遺伝子のトランスジェニックラットや病態モデル動物 (SAM p1/Y4)を無菌化または SPF 化することで, 腸炎 がみられなくなることが多数報告されている( ${ }^{(8)}$.これら の結果は, IBD の発症に扔ける腸内フローラと免疫異 常の関与を強く示唆している。しかし，長年にわたる検 索にもかかわらず，特定の原因菌はいまだに見いだされ ていない. IBD 患者の腸内フローラでは, Bifidobacter ium や Lactobacillus の減少, Clostridium perfringens や好気性菌の増加が報告されているが，これらの変化は “異常フローラ”といわれるときのパターンと同じであ り, IBD 特有のパターンとは言えない。一方, IBD の 原因が腸内細菌に対する免疫寛容の破綻であるとの説明 が行なわれるようになり，Bacteroides vulgatus の定着 もその一つと考えられている.

IBD の治療面では, 免疫寛容の修復と腸内フローラの 改善の 2 つ面が考光られる. その一つとしてプロバイ
オティクスの投与が試みられ，一定の有効性も報告され ている ${ }^{(9)}$. しかし, 症例や使用菌株により効果がみられ ないとの報告もある，プロバイオティクスは多くの免疫 調節機能があり ${ }^{(10)}$, 今後より詳細な研究が必要となる.

\section{4. 外来病原菌に対する感染予防}

外来病原菌に対する防御は, 腸内フローラの機能の面 で最も古くから知られており, 多くの研究がなされてき た. 無菌動物に特定の大腸菌, サルモネラ菌株などを単 独投与すれば $10^{9} / \mathrm{g}$ レベルまで腸内に定着できるが, 通 常動物では一週間以内に腸管から排除される. 外来病原 菌の排除メカニズムとしては, (1)腸管粘膜上皮や粘膜層 において定着する場の常在細菌との競合, (2)腸管内, 粘 膜層内に打ける常在細菌との栄養素の奪い合い, (3)常在 細菌によるインヒビターの産生などが主に考えられてい るが，ヒトにおいてどのような菌種がどのようなメカニ ズムで外来病原菌を排除しているかは依然不明である.

腸内フローラによる bacterial translocation（腸内に 生息する生菌が腸管以外の臓器に移行する現象) 抑制効 果の第一歩は, 腸内における特定菌種の異常増殖を抑制 することである. プロバイオティクスによる外来病原細 菌の抑制効果については多くの報告があるが, IgA 産生 などの免疫機能の増強とインヒビターの産生が主な作用 と考えられる. 外来病原菌の定着と bacterial translocation を誘発する腸内での特定菌種の異常増殖は “ノーマ ルフローラ (各動物に固有の安定したフローラ)” を保持 している状態では起こりにくい. プロバイオティクス, プレバイオティクスの有効性にはその定義にある「腸内 環境を改善して」という基本的な作用が重要である.

\section{5. 過敏性腸症候群の治療}

過敏性腸症候群 (irritable bowel syndrom；IBS) は, 消化管の運動異常や “brain-gut interactions(脳腸相 関)”による中枢神経系の異常, さらに消化管ホルモン の異常によると考えられている. プロバイオティクスを 用いた治療も試みられているが, 腸内フローラとの関係 については多くの検討が必要となろう.

\section{腸内フローラ研究の新しい流れ}

前述のように, 各種病態への腸内フローラの関与につ いては多くのデータがこれを示している. しかし, 腸内 フローラがどのように病態に関与しているか, またプロ バイオティクス, プレバイオティクスによる腸内の環境 の改善とは何を意味しているかなど, 腸内フローラと宿 


\section{分子遺伝学的手法}

16S rDNAの塩基配列を利用した FISH法, 定量的PCR法

\section{ヒトモデル実験系の利用}

ヒトフローラマウスの作出

人工腸管のシステムの作製

遺伝子改変動物のノトバイオートの作出

腸内フローラ細菌-宿主間などの“cross-talk”

フェロモン様物質による遺伝子発現コントロール マウスを用いた宿主細胞の遺伝子発現の比較

図 4 曰腸内フローラ研究の新しい流れ

主をつなぐ基本的なメカニズムが明らかにならないと， 腸内フローラ研究の最終的な目標の一つである「腸内フ ローラをコントロールして健康維持に貢献する」ことに つながらない. 近年，バイオサイエンスの分野では新た な技術が次々と開発され，腸内フローラの研究にも応用 されてきている(図4).

\section{1. 培養によらない腸内フローラ検索法}

従来の腸内フローラ検索は, 非選択培地と選択培地を 組み合わせ，種々の嫌気性培養装置を用いた培養法で行 なわれてきた ${ }^{(11)}$ 。これらは腸内フローラに対する認識を 一変させ, 現在の腸内フローラ研究, プロバイオティク ス, プレバイオティクス開発の基礎を築いた。しかし， 絶対嫌気性菌を主とする腸内フローラの培養は高度の技 術が必要で, 分離された菌種の同定も熟練を要するもの であるため，かなりの困難を伴っていることも事実であ る.また培養法自体もある種の選択的方法であり，報告 により違いがあるが，培養できる細菌は直接顕微鏡で見 られる菌数の 20 ～ $50 \%$ といわれ，残りは死菌, 難培養性 のものが含まれている.

90 年代に入り微生物の系統分類の進歩に伴い, 多くの 遺伝情報が蓄積されて微生物分類学にも分子遺伝学的手 法 ${ }^{(2)}$ が取り入れられた. 腸内フローラの検索において も, 培養によらない解析法として, 細菌の $16 \mathrm{~S}$ rDNA の 塩基配列を利用した FISH 法 ${ }^{(13)}$ や定量的 PCR 法(14) が システムとして確立されている。これらの手法は，培養 法に比べて迅速に結果を出すことはできるが，今までの ところ培養法で得られた結果以上のものは得られていな い.また，これらの方法は優勢に存在する菌種のみの解 析であり, 適切な選択培地を用いた場合よりも検出限 界がかなり高くなる。つまり，腸内フローラのように
$10^{2} \sim 10^{11} / \mathrm{g}$ と, 菌種により定着している菌数に極端な差 のある材料をどのように検索していくかは今後の課題と いえる.

さらに，16S rDNA のデータをもとに系統樹を作成す ると, 腸内フローラ構成菌種のうち Bifidobacterium 属 以外のヒト腸内フローラで重要と考えられるClostridium, Bacteroides, Eubacterium などは従来の系統樹 上で異なる属の菌種が同じクラスターに含まれること もあり, 得られたデータと従来のデータとの整合性をは かる必要がある．また，DNA チップ法や生物の多様性 解析法として terminal restriction fragment length polymorphism (T-RFLP) 法や denatuning/temperature gradient gel electrophoresis (D/TGGE) 法など も用いられるようになってきた。多様性解析法において は, 出現するピークやバンドの違いにより微生物コミュ ニティの違いを比較することは容易である. しかし，最 終的に菌叢にどのような違いがあるのかを想定する一つ の方法としては有効であるものの，パターンの違いだけ で生物学的意味づけを行なうことは難しい. 各菌種にお ける rDNA のコピー数や DNA の抽出効率の違い, 検出 できる菌群は最優勢に生息するものに偏る点など, 今後 の検討課題も多い.

腸内フローラ構成を解析するには，培養法，分子遺伝 学的手法など, 多方面からの解析が重要となる．腸内菌 それぞれの活性を明らかにし，最終的には宿主の健康に 寄与するようにコントロールするためには “生きた菌” としてとらえる努力, 培養法や培地の開発も怠ってはな らない.

\section{2. モデル実験系としてのヒトフローラマウスならびに 人工腸管}

ヒト腸内フローラの研究は，ヒトそのものを用いた場 合，個体差が大きく，また発癌やアレルギーなど病態の 実験は行なうことができない.さらにマウス，ラットは その腸内フローラがヒトと著しく異なるため, 代謝の研 究では外挿できないことが多い。そこで，ヒトの腸内フ ローラをそのまま無菌マウスに移植して，七ト腸内研究 用動物として “ヒトフローラマウス”の作出が行なわれ てきた。しかし，ヒトフローラマウスの腸内フローラの 構成と機能が必ずしも投与したヒ卜糞便の性状と一致し ないものもあり ${ }^{(15)}$ ，使用に当たっては研究目的にそっ たものであるかどうかを検証する必要がある。一方，マ ウスには多くの病態モデルがあり，ヒト腸内フローラの 影響や作用機序を研究するモデルとしては有効な手段と なる。また，ヒ卜腸内でみられる腸内菌の代謝を無菌マ 
ウスに移植できる場合, それに関与する菌種, 菌群を特 定することができる.

一つの例として, 胆汁酸の代謝経路はヒトフローラマ ウス腸内でも再現でき,さらに通常マウスの腸内でみら れる特徴的な二次胆汁酸である心ームリコール酸は, ヒ トフローラマウスでは産生されずヒト腸内に近いパター ンとなる ${ }^{(16)}$. このヒトフローラマウス腸内フローラを分 画して各種ノトバイオートマウスを作出することで, 胆 汁酸の腸内代謝に関与する菌種の組合せを明らかにする ことができた。このように利用の仕方により有用な実験 材料となり得るが, 今後の課題として, ヒトの腸内フロ ーラ構成をノトバイオートとして人工合成する，つまり 目的別にスタンダードフローラを作製することが挙げら れる. 培養可能な菌種のみでヒト腸内フローラの機能を 再現できれば, 難培養性菌群の生物学的意味づけも明ら かにできると考えられる。

ヒトフローラマウスよりもさらに人工的な実験手段と して, 人工腸管のシステムが作られている. 以前は嫌気 性連続流動培養装置といった単純な装置で行なわれてい たが，ヒトの腸管をイメージした二層式, 三層式の装置 が考案されてきた.さらにオランダの Venema らのグル ープは, コンピュータ制御により腸内の $\mathrm{pH}$ や流動速度 などをコントロールし，また吸収層をも装着した “人工 腸管”ともいえる装置を開発した。彼らは ex-vivo シス テムと表現している ${ }^{(17)}$. 人工腸管は, 主に腸内代謝の研 究に用いられているが, 特に腸内腐敗の研究の場合, 七 トフローラマウスでは著しく腸内腐敗産物の生成が抑制 されてしまうのに対し, ex-vivo システムではヒトの腸 内腐敗が再現できるという特徵がある. 腸内代謝の研究 では, 腸管の途中段階でのサンプリングや物質レベル研 究, 腸内菌ひとつひとつの活性の評価などが必要である が, ex-vivo システムはこのような研究に今後ますます 活用されるであろう. 高齢化社会を迎え腸内腐敗は社会 的問題であるが, これらの抑制のための機能性食品の開 発にも有用な手段を提供するものと考えられる.

\section{3. 腸内フローラと宿主の “cross-talk”}

腸内フローラは，数十万年にもわたり宿主と共存関係 を作り上げてきた，細菌は, 腸管という一つの環境の中 でそこに適応できるものだけが生き残り，いわゆるノー マルフローラを形成した．それぞれの動物の食性を含め た腸内環境の違いが，動物種ごとの，また年齢ごとの腸 内フローラ構成の違いとなって表現されている. しか し, なぜ動物ごと, 年齢ごとで定着する菌種が異なるか は不明のままである。
近年，ゲノムやタンパク質の解析技術が飛躍的に進歩 し，それらを腸内フローラ研究に取り入れることで，遺 伝子発現調節の cross-talk の新たな展開がみられてい る．腸内フローラと宿主との関係を考えるとき,細菌-細 菌, 細菌-宿主間にはそれぞれの cross-talk が存在し, きわめて複雑なコミュニティーを形成している(18).

細菌相互の関係としては, クオーラムセンシングとし て知られているフェロモン様物質による遺伝子発現の コントロールが報告されている ${ }^{(19)}$.多くの腸内病原体 で autoinducerにより病原因子，たとえば腸管出血性大 腸菌の定着・Stx 産生, Campylobacter jejuni の CDT (Cytolethal distending toxin) の産生などがコントロー ルされている ${ }^{(20)}$. バクテリオシン産生も，このシステム によりコントロールされる。しかし, 腸内フローラ構成 菌におけるこれらのシグナリングシステムがどのように 作用しているかについてはほとんど知られていない。ま た, 細菌-細菌間の cross-talk は腸管粘膜を覆う粘膜層 （バイオフィルムの一つ）での腸内菌構成にも影響する。 バイオフィルムの形成は腸管感染の際の生体防御に重要 な働きをするとともに，腸内フローラ構成の “種”とな る機能を有する．細菌-細菌間の cross-talk は種々の環 境条件に左右されることが多く，in vitro では発現する 遺伝子が in vivoでは発現しなかったり, その逆の場合 もある. 多くの病原菌や食品関連細菌のゲノム解析が行 なわれているが, 腸内フローラ構成菌についてはほとん ど手がつけられていない. 腸内フローラには viable but nonculturable (VBNC) を含めた培養困難な菌が全体の $50 \%$ 以上存在すると考えられ，これらの菌も含めた腸内 菌それぞれのゲノム解析は, 複雑な生態系を解析する上 に不可欠となり, in vivo の細菌-細菌間のコミュニケー ションを理解する有力な武器となろう.

細菌-宿主間の cross-talkにおいても, 細菌は宿主の 遺伝子発現に大きな影響を与える. 無菌マウス, 通常マ ウス，ならびに特定の菌種を無菌マウスに定着させたノ トバイオートマウスを用いて, 宿主細胞の各種遺伝子の 発現を比較した結果が報告されている(21,22). また, cell line を用いた実験で, black-pigmented Bacteroides が 細胞の IL-8 遺伝子の発現に関与しているとの報告があ $ろ^{(23)}$. Bacteroides thetaiotaomicron 単独投与マウスで 発現が調整された宿主遺伝子群は, 他の菌種の単独投 与では発現誘導されないものもあり, 宿主と腸内菌の cross-talk は菌種ごとに異なる ${ }^{(24)}$.

今後, 無菌動物に各種細菌を投与したノトバイオート を作出し, 宿主側のゲノムと細菌側のゲノムの解析 ${ }^{(25)} を$ 通して, 生体機能を健康な状態に維持・誘導するための 
宿主側，菌側のマーカーを明らかにしていくことで，新 たなプロバイオティクス，プレバイオティクスの開発に つながるものと考える．さらに，それらのマーカーを利 用した Genetic modified organisms $(\mathrm{GMO})^{(26)}$ を作出 して，より有効性の高いプロバイオティクスを開発でき る.一例として, IBD のモデルである IL-10 ノックアウ トマウスに IL-10 遺伝子を導入した Lactococcus lactis を投与することで結腸内に IL-10 が合成され，結腸炎の 抑制がみられた ${ }^{(27)}$.このような GMO 開発は，プロバイ オティクスの一つの方向性を示すものと考える.

\section{*}

以上述べてきたように，腸内フローラと宿主との関係 は密接であり, 今後, 医薬品や食品の生体への影響を考 える場合 “腸内フローラとヒト”をセットで理解するこ とが必要となるだろう。また，プロバイオティクスやプ レバイオティクスの効果の基本である「腸内環境の改 善」を数値化するための検查法の機械化, 効果のメカニ ズムを明らかにするための宿主-腸内菌のゲノム解析, 機能解析が重要となる。

\section{文献}

1) T. Mitsuoka : Bioscience Microflora, 19, 15 (2000).

2) 光岡知足 : “腸内フローラとプロバイオティクス”, 学会出版 センター, 1998, p.1.

3) T. Mizutani \& T. Mitsuoka : J. Natl. Cancer Inst., 63, 1365 (1979).

4) S. Narushima, K. Itoh, K. Kuruma \& K. Uchida : Microb. Ecol. Health Dis., 11, 55 (1999).

5) K. Ohno, S. Narushima, S. Takeuchi, K. Itoh, T. Itoh, K. Hioki \& T. Nomura : J. Exp. Clin. Cancer Res., 20, 51 (2001).

6) E. Isolauri, T. Arvola, Y. Sütas, E. Moilanen \& Salminen : Clin. Exp. Allerg., 30, 1604 (2000).

7) R. Lodinová-Zádníková, B. Cukrowska \& H. TlaskalovaHogenova : Allerg. Immunol., 131, 209 (2003).

8) S. Matsumoto, N. Watanabe, Y. Okabe \& Y. Umesaki : Bioscience Microflora, 18, 1 (1999).

9) K.M. Tuohy, H.M. Probent, C.W. Snejkel \& G.K. Gibon : Drug Discovery Today, 8, 692 (2003).

10) R. Heroch \& M. Levkut : Vet. Med.-Czech, 47, 169 (2002).

11）光岡知足：臨床検查, 23,320 (1979).

12）春田 伸：腸内細菌学雑誌, 18, 39 (2004).

13) G. Welling, L. Wildeboer-Veloo, G.C. Raags, A.H. Franks, G.J. Jansen, R.H.J. Tonk, J.E. Degener \& H.J.M. Harmsen : “腸内フローラの分子生態学的検出・同定”, 学会出版セ ンター, 2000, p.7.

14）松木隆広, 宮本有希子, 渡辺幸一, 田中隆一郎, 小柳津広： “腸内フローラの分子生態学的検出・同定”, 学会出版セン夕 -, 2000, p.67.

15) K. Hirayama, K. Itoh, E. Takahashi \& T. Mitsuoka : Microb. Ecol. Health Dis., 8, 199 (1995).

16) S. Narushima, K. Itoh, K. Kuruma \& K. Uchida : Lipids, 35, 639 (2000).
17) K. Venema, H.M.C. van Nuenen, E.G. van der Heuvel, W. Pool \& J.M.B.M. van der Vossen:Microb. Ecol. Health Dis., 15, 94 (2003).

18) M. Freitas, E. Tavan, C. Cayuela, L. Diop, C. Sapin \& G. Trugnan: Biol. Cell, 95, 503 (2003).

19) K.L. Anderson : Can. J. Anim. Sci., 83, 409 (2003).

20) V. Sperandio, A.G. Torres, B. Jarvis, J.P. Nataro \& J.B. Kaper: Proc. Natl. Acad. Sci. USA, 100, 8951 (2003).

21) L. Hooper, M.H. Wong, A. Thelin, L. Hansson, P.G. Falk \& J.I. Gordon: Science, 291, 881 (2001).

22) K. Fukushima, H. Ogawa, K. Takahashi, H. Naito, Y. Funatama, T. Kitayama, H. Yonezawa \& I. Sasaki : Scand. J. Gastroenterol., 38, 626 (2003).

23) L.-C. Yong, F.-M. Huang, C.-S. Lin, C.-M. Liu, C.-C. Lai \& Y.-C. Chang: Int. Endodontic J., 36, 774 (2003).

24) P. Falk：腸内細菌学雑誌， 16, 115 (2002).

25) J. Xu, M.K. Bjursell, J. Himrod, S. Deng, L.K. Carmichael, H.C. Chiang, L.V. Hooper \& J.I. Gordon : Science, 299, 2074 (2003).

26) A. von Wright \& Å. Bruce: Trends Food Sci. Technol., 14, 264 (2003).

27) L. Steidler, W. Hans, L. Schotte, S. Neirynck, F. Obermeier, W. Falk, W. Fiers \& E. Renaut : Science, 289, 1352 (2000). 